\title{
EVALUATION OF AERIAL SPRAY TECHNOLOGIES FOR ADULT MOSQUITO CONTROL APPLICATIONS
}

\author{
Wesley Clint Hoffmann ${ }^{1}$, Bradley Keith Fritz ${ }^{1}$, Muhammad Farooq ${ }^{2}$, Todd William Walker ${ }^{2}$, \\ Zbigniew Czaczyk ${ }^{3 *}$, Jonathan Hornsby ${ }^{4}$, Jane Annalise Sara Bonds ${ }^{5}$
}

\author{
${ }^{1}$ USDA-ARS, 2771 F\&B Road, College Station, USA, TX 77845 \\ ${ }^{2}$ US Navy-Naval Entomology Center of Excellence, Bld. 437, Jacksonville, USA, FL 32212 \\ ${ }^{3}$ Poznań University of Life Sciences, Wojska Polskiego 28, 60-637 Poznań, Poland \\ ${ }^{4}$ Lee County Mosquito Control District, P.O. Box 32003, Ft. Myers, USA, FL 33906 \\ ${ }^{5}$ Florida A\&M University, 4000 Frankford Avenue, Panama City, USA, FL 32405-1933
}

Received: August 21, 2012

Accepted: July 19, 2013

\begin{abstract}
Spray droplet size has long been recognized as an important variable that applicators of vector control sprays must be aware of to make the most effective spray applications. Researchers and applicators have several different techniques available to assess spray droplet size from spray nozzles. The objective of this study was to compare the droplet size spectrum produced by three nozzles commonly used in vector control in a high-speed wind tunnel, when characterized using three different laser-based droplet size measurement systems.

Three droplet sizing systems: Malvern Spraytec laser diffraction, Sympatec HELOS laser diffraction, and TSI Phase Doppler Particle Analyzer (PDPA), were simultaneously operated, but under different operating conditions, to measure the spray droplet size-spectra for three spray nozzles. The three atomizers: a TeeJet ${ }^{\circledR}$ 8001E even flat fan nozzle, a BETE ${ }^{\circledR}$ PJ high pressure fog nozzles, and a Micronair ${ }^{\circledR}$ AU5000 rotary atomizer were evaluated in a high speed wind tunnel at airspeeds of 53 and $62 \mathrm{~m} / \mathrm{s}$ (120 and $\left.140 \mathrm{mph}\right)$. Based on the results of this work, only the BETE ${ }^{\oplus J}$ P high pressure fog nozzles met the label requirements for both Fyfanon ${ }^{\circledR}$ and Anvil ${ }^{\circledR}$. While the other nozzle might met the $\mathrm{D}_{\mathrm{v} 0.5}$ (VMD - volume median diameter) requirement for Fyfanon ${ }^{\circledR}$, the resulting $\mathrm{D}_{\mathrm{v} 0.9}$ values exceeded labeled size restrictions. When applying Anvil with the BETE PJ high pressure fog nozzles, it is important to use the smaller two orifice sizes. The larger sizes tended to result in $\mathrm{D}_{\mathrm{v} 0.9}$ values that exceeded label recommendations.
\end{abstract}

Key words: aerial application, atomization, mosquito working parameters, nozzles, spray nozzles, vector control

\section{INTRODUCTION}

Arthropod vectors are typically controlled with either ground or aerially applied insecticides. Droplet size is one of the most important factors with respect to adult mosquito control. For this reason, the application technologies being used must generate sprays that are efficacious and meet the specifications required by product labels. Ledson and Matthews (1992) recommended using sprays with volume median diameters $\left(D_{v 0.5}-\right.$ the droplet diameter such that $50 \%$ of the spray volume is comprised of droplets of equal or lesser value $\equiv \mathrm{VMD}$ - volume median diameter) less the $30 \mu \mathrm{m}$. This recommendation was further supported by the World Health Organization (WHO 2006a, 2006b). Similar size recommendations were reported by others, including Mount (1985), who reported an optimum size range between 8 and $15 \mu \mathrm{m}$, Haile et al. (1982) who reported peak mortality with droplets between 7 and $22 \mu \mathrm{m}$, and Clayton and Sander (2002) who reported the optimal range of droplets for mosquito control to be between 10 and $30 \mu \mathrm{m}$.
Labeled droplet size restrictions for pesticide products used in vector control operations typically set $\mathrm{D}_{\mathrm{v} 0.5}$ (VMD) values between 8 and $30 \mu \mathrm{m}$. Droplet size restrictions further require that no less than $90 \%$ of the spray volume consist of spray droplet less than $50 \mu \mathrm{m}$. For aerial applications, Fyfanon ${ }^{\circledR}$ ULV Mosquito insecticide (EPA Reg. No. 97760-34, Cheminova, Research Triangle Park, NC, active ingredient: Malathion) states that "spray equipment must be adjusted so the volume median diameter $\left(\mathrm{VMD} \equiv \mathrm{D}_{\mathrm{v} 0.5}\right)$ produced is less than $60 \mu \mathrm{m}\left(\mathrm{D}_{\mathrm{v} 0.5}\right.$ $<60 \mu \mathrm{m}$ ) and that $90 \%$ of the spray is contained in droplets smaller than $100 \mu \mathrm{m}\left(\mathrm{D}_{\mathrm{v} 0.9}<100 \mu \mathrm{m}\right)$ ". The label for Anvil $^{\circledR}$ 10+10 ULV insecticide (Clarke Mosquito Control, Roselle, IL, active ingredients: 10\% Sumithrin and 10\% Piperonyl butoxide) states that "for aerial applications, the VMD is 8 to $30 \mu \mathrm{m}\left(8<\mathrm{D}_{\mathrm{v} 0.5}<30 \mu \mathrm{m}\right)$ and that $90 \%$ of the spray be contained in droplets smaller than $50 \mu \mathrm{m}\left(\mathrm{D}_{\mathrm{v} 0.9}\right.$ $<50 \mu \mathrm{m})^{\prime \prime}$. Users are required to select application equipment and operational parameters that produce sprays that meet these label restrictions. 
Over the past 6 years, collaborative efforts between the U.S. Department of Agriculture, Agricultural Research Service Aerial Application Technology (AAT) group in College Station, Texas, and the U.S. Navy - Navy Entomological Center of Excellence (NECE) in Jacksonville, FL have focused on evaluating various vector control application technologies used by deployed warfighters. To date, these evaluations have focused on the measurement of the spray droplet spectrum resulting from application made using handheld, backpack, and truck-mounted ultra-low volume (ULV), and thermal and cold fogging technologies (Hoffmann et al. 2007a, 2007b, 2008, 2009). This work is a continuation of these collaborative efforts. The focus of our work is on evaluating aerial technologies, used for adult control.

Typical hydraulic nozzles used to apply agricultural protection products, are not capable of producing droplet mean diameters in the sub $30 \mu \mathrm{m}$ size range as required for vector control operations (Kirk 2007). However, there are spray nozzles that are reportedly being used effectively in aerial adult control studies or spray programs. Clayton and Sander (2002), and Dukes et al. (2004a) reported on the use of flat fan nozzles oriented $45^{\circ}$ into the oncoming airstream, while Clayton and Sander (2002), Mabbett (2002) and Lothrop et al. (2007) reported using rotary atomizers. Another nozzle, the BETE PJ nozzle (BETE Fog Nozzle, Inc., Greenfield, MA), is used both by the Pasco County Mosquito Control District (Pasco County, FL) and the Beach Mosquito Control District (Bay County, FL).
The first objective of this work was to evaluate the performance of flat fan nozzle (TeeJet ${ }^{\circledR}$ 8001E), misting (BETE PJ) nozzles, and the rotary atomizer (Micronair AU5000) used in aerial adult control applications under typical application airspeeds and operational setups. The second objective was to provide guidance to users so they can comply with insecticide label requirements.

\section{MATERIALS AND METHODS}

\section{Nozzles Tested}

- Based on the three types of nozzles identified earlier, three specificnozzles were chosen for these tests (Fig.1). The three types are described below:

- TeeJet ${ }^{\circledR}$ 8001E (even) flat fan nozzle (Spraying Systems ${ }^{\circledR}$, Wheaton, IL).

The nozzle was orientated at $135^{\circ}\left(45^{\circ}\right.$ into the airstream - Fig. 1). Tests were conducted at 276 and $410 \mathrm{kPa}$ (40 and 60 psi) liquid pressures, which corresponded to flow rates of 0.53 and $0.64 \mathrm{l} / \mathrm{min}(0.14$ and $0.17 \mathrm{gal} / \mathrm{min})$.

- BETE PJ high pressure fog (misting) nozzles (BETE nozzles, Thomas Agency, Winter Park, FL).

Four different PJ nozzles were evaluated: PJ15, PJ20, PJ24, and PJ32. The number after the PJ denotes the orifice diameter in 1/1,000 of an inch (PJ15 - orifice diameter of 0.015 inches). At a liquid pressure of $6.9 \mathrm{MPa}(1,000$ psi), the flow rates for the PJ15, PJ20, PJ24 and PJ32 nozzles were $0.72,1.29,1.89$, and $3.41 \mathrm{l} / \mathrm{min}(0.19,0.34,0.50$ and $0.90 \mathrm{gal} / \mathrm{min})$, respectively. All four PJ nozzles were

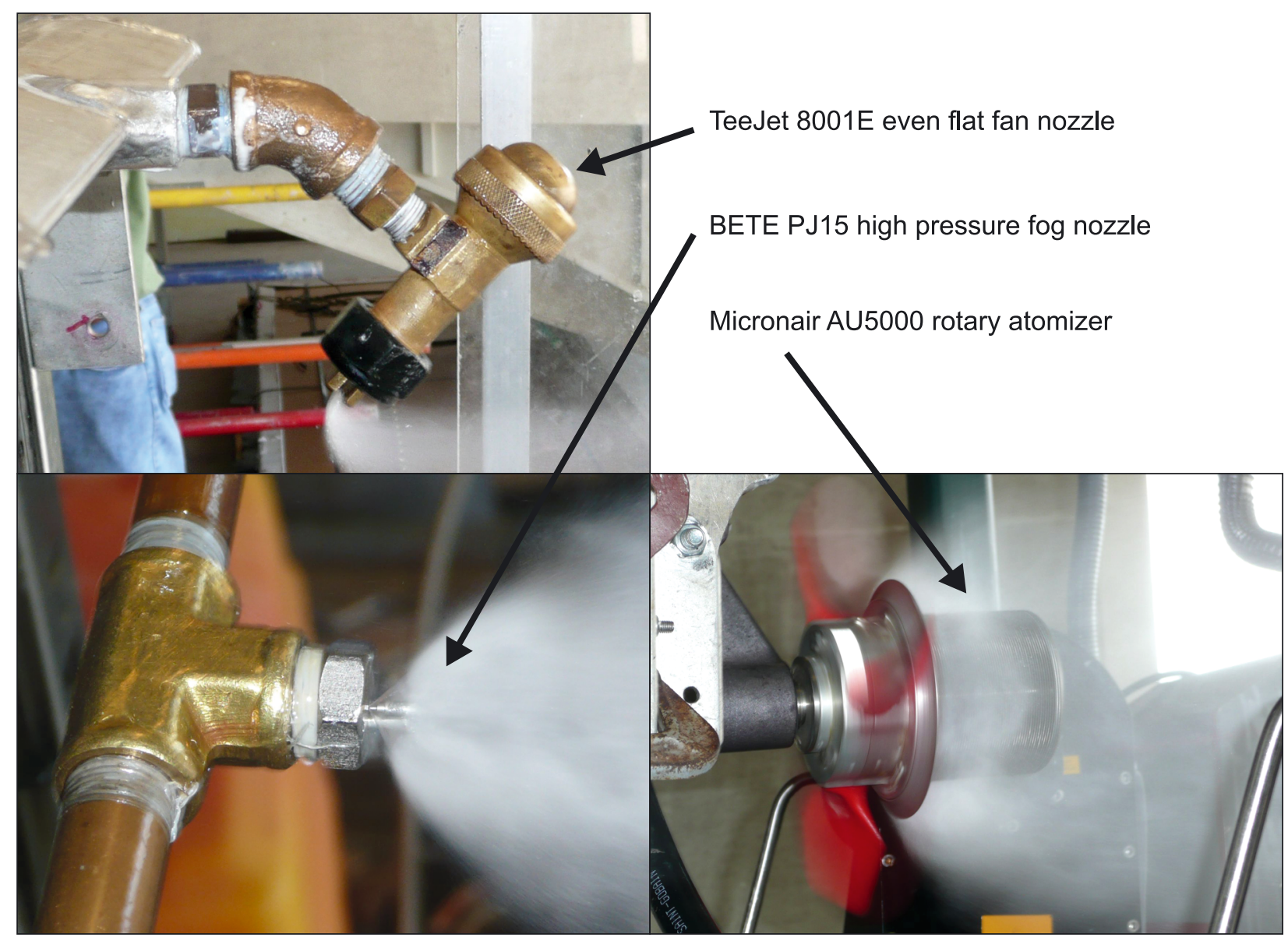

Fig. 1. Nozzles evaluated in the laser comparison study. Each nozzle is shown while spraying in a high velocity airstream 
orientated at $0^{\circ}$ (i.e. straight back and parallel to the airstream). The nozzles were evaluated at pressures: 6.9 and 10.3 MPa (1,000 and 1,500 psi).

- Micronair AU5000 rotary atomizer (Micron Sprayers

Limited, Herefordshire, UK).

The blades on the atomizer were set at Blade Position $\# 4$ to give an approximate rotational speed of $10,000 \mathrm{rpm}$ in a $63 \mathrm{~m} / \mathrm{s}$ (140 mph) airstream, as confirmed by an optical tachometer. The AU5000 atomizer was evaluated at 138,276 , and $410 \mathrm{kPa}(20,40$, and $60 \mathrm{psi})$ liquid pressures, with $\# 2$ and \#4 restrictor orifices to control flow rate. The Micronair atomizer was mounted in a fixed position so that the axis of rotation was parallel to the airstream.

\section{Measurement of the Spray Droplet Spectrum}

As this was a collaborative effort between research entities, several droplet sizing instruments were included; the USDA ARS ATT's Sympatec HELOS laser diffraction system; Manatee County's Malvern Spraytec laser diffraction system, and NECE's TDI Phase Doppler Particle Analyzer (PDPA). It should be noted that this work was not designed to directly compare the measurement systems, but rather to evaluate the nozzles. Comparisons between system results are limited to whether or not the use of these different systems would result in the same recommendation of use for a particular nozzle and setup. Brief operational information and setups of the different systems are included below.

The Sympatec HELOS laser diffraction droplet sizing system (Sympatec Inc., Clausthal, Germany) uses a $623 \mathrm{~nm}$ He-Ne laser and was fitted with an R5 lens, for a dynamic size range from $0.5 \mu \mathrm{m}$ to $875 \mu \mathrm{m}$ in 32 sizing bins. A forklift mounted frame suspended the system in such a way that the laser beam was centered vertically downwind of the tunnel outlet. Due to this mounting technique, the last channel (i.e. sizing bins) of the HELOS system was turned off because background vibrations created a "spiked" reading in this last channel. This channel was not turned off if any droplets were measured within two sizing bins. This did not occur during our study as no droplets greater than $515 \mu \mathrm{m}$ in diameter were measured during any of the atomization tests.

The Malvern Spraytec laser diffraction particle size analysis system (Malvern, Instruments Ltd. UK) uses a $670 \mathrm{~nm}$ laser diode with a beam scan diameter of $10 \mathrm{~mm}$. The Insitec RTSizer ("Real-time Sizer") for Windows (ver. 5.41) software collected data in real time at up to $2.5 \mathrm{kHz}$. Model-independent analysis was incorporated with correction for "multiple scattering". The laser was mounted on Malvern's long bench which provides a 500 $\mathrm{mm}$ spray gap, and was fitted with a $450 \mathrm{~mm}$ focal length lens having a working distance of $675 \mathrm{~mm}$. The lens used, provided a droplet measurement range of $2.25 \mu \mathrm{m}$ to 850 $\mu \mathrm{m}$ - distributed over 30 sizing bins.

The 2D Phase Doppler Particle Analyzer (PDPA) system (TSI Inc., Shoreview, MN) consists of a laser head, beam color separator and splitter, fiber optic transmitter, receiver, and a signal processor. The head generates an argon ion laser that has a power range of from 0 to $6 \mathrm{~W}$. The beam separator separates the incident beam into green $(514.5 \mathrm{~nm})$, blue $(488 \mathrm{~nm})$, and cyan $(476.5 \mathrm{~nm})$ colors. It also splits each color beam into two beams of equal intensity. One of each of these beams is shifted in frequency by $40 \mathrm{MHz}$. The shifted and non-shifted beams are transported to the transmitter through fiber optic cables. The same color beams are converged to cross at the focal length, depending upon the lens installed on the transmitter. For the current study, the transmitter had $250 \mathrm{~mm}$ lens while the receiver had $300 \mathrm{~mm}$ lens. The set up resulted in a measurable droplet size range of 0.6-211 $\mu \mathrm{m}$. Each droplet is measured independently and 50,000 to 200,000 droplets were measured during each capture (i.e. replication). The bin size was set at $1 \mu \mathrm{m}$ with a total of 210 bins, although up to 5,000 bins could be used. The PDPA reported droplet number and volume distribution as well as velocity distribution.

\section{Testing Procedure}

All tests were conducted at the high speed wind tunnel (HSWT), at USDA-ARS in College Station, TX (Fig. 2). The USDA-ARS HSWT consists of a high speed centrifugal blower powered by a $48.5 \mathrm{~kW}(65 \mathrm{hp})$ gasoline engine. The blower speed is controlled by adjusting the engine's throttle. The high speed air generated by the blower, exhausts through a $30 \times 30 \mathrm{~cm}$ outlet. Prior to leaving the outlet, the high speed air passes through air straighteners mounted inside the tunnel. The air velocity is measured directly at the outlet, using a Pitot tube attached to an airspeed indicator. A $30 \mathrm{~cm}$ section of aircraft boom is mounted directly at the tunnel's outlet (Fig. 1 - TeeJet ${ }^{\circledR} 8001 \mathrm{E}$ even flat fan nozzle). The boom is affixed to a pair of linear slides and a linear motor to traverse the nozzle vertically. In this way, the entire spray plume traverses the optical path of the laser measurement systems. The boom section is plumbed to a pressured spray tank. The center of the boom has a fitting to mount the required check valves and nozzles. A pressure gauge is also plumbed to the boom to monitor pressure at the nozzle. The selected spray nozzles were tested at 54 and $63 \mathrm{~m} / \mathrm{s}$ (120 and $140 \mathrm{mph}$ ) of air velocity. During the tests, the air temperature ranged from $20-27^{\circ} \mathrm{C}(68-$ $80^{\circ} \mathrm{F}$ ) and relative humidity ranged from $65-90 \%$. Since the spray solution was an oil, and all measurements were made within $0.6 \mathrm{~m}$ of the nozzle, evaporative effects on droplet size were negligible.

The test solution used in this evaluation was BVA 13 ULV Oil (Severely Hydro-treated Paraffinic Oil, Adapco Inc., Sanford, FL), which is a commonly used material in vector control applications. All measurements were made with two of the three systems mounted downwind of the nozzles: Sympatec and Malvern, then Sympatec and PDPA (Figs. 2, 3). Again, this was not done to compare systems, but rather to provide a data quality check between measurement replications to insure that nozzle and wind tunnel operational setups remained consistent.

\section{Droplet Size Parameters}

The spray droplet size data were determined and reported as a mean $(\mu \mathrm{m})$ and standard deviation corresponding to the data measured during the three replications for each combination of nozzle, airspeed, and/or pressure. Means and standard deviations of the volume 


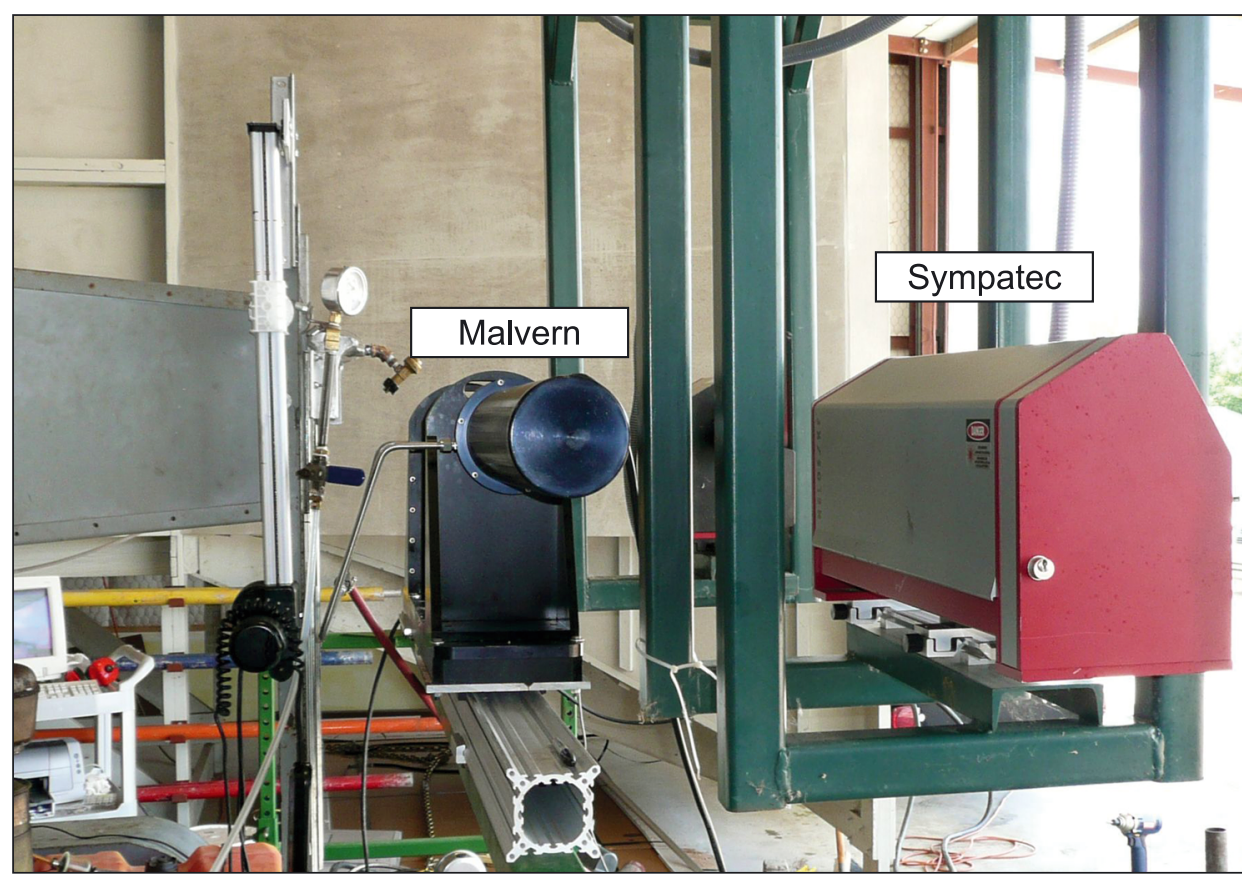

Fig. 2. Malvern Spraytec and Sympatec HELOS particle size measurement systems positioned at the exit of the high speed wind tunnel (HSWT)

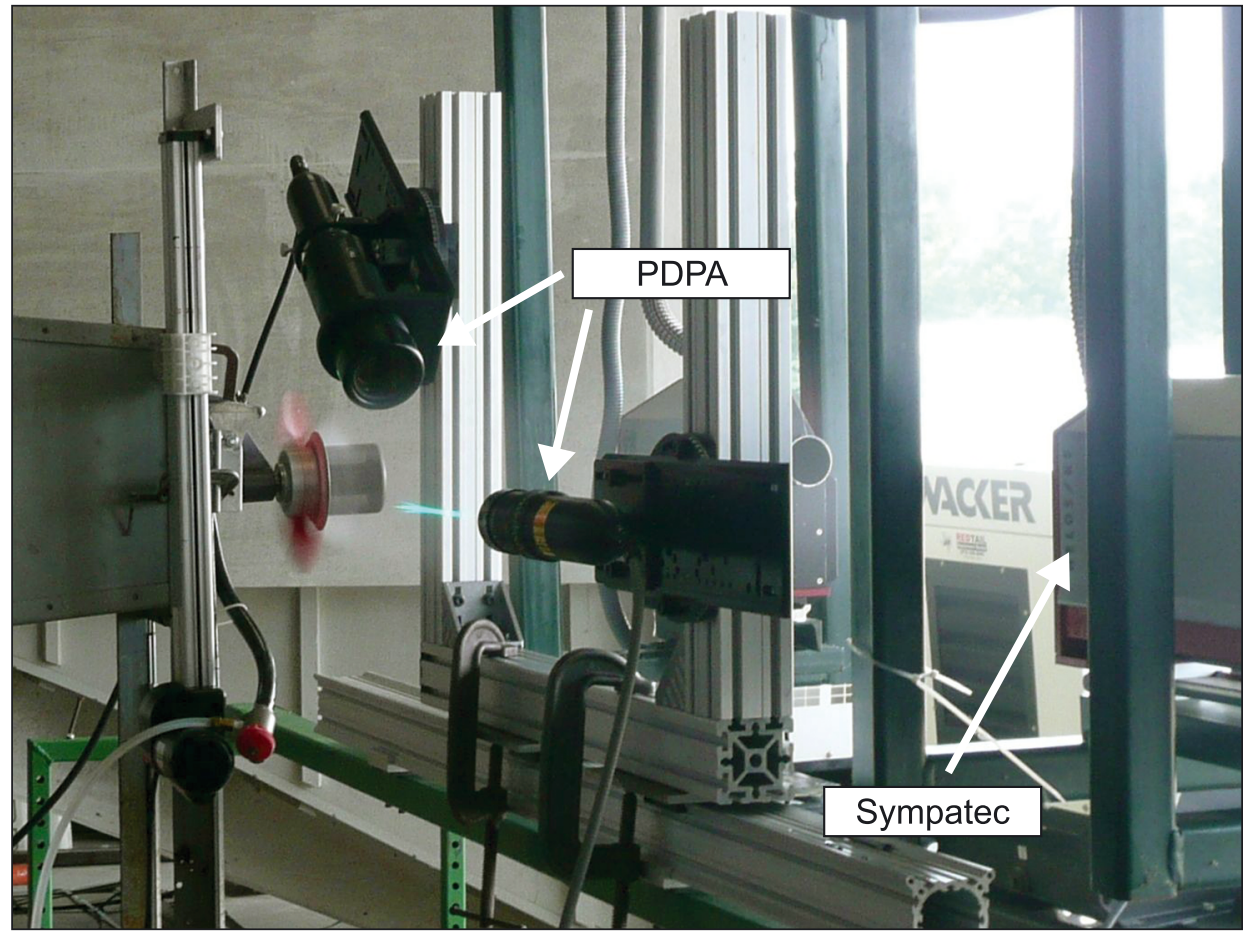

Fig. 3. Phase Doppler Particle Analyzer (PDPA) and Sympatec HELOS particle size measurement systems positioned at the exit of the high speed wind tunnel (HSWT)

median diameter (VMD or $\left.\mathrm{D}_{\mathrm{v} 0.5}\right), \mathrm{D}_{\mathrm{v} 0.1}$ and $\mathrm{D}_{\mathrm{v} 0.9}$ across the three replicated measurements taken at each operational setup point were determined (American Society for Testing Materials International 2004). The $\mathrm{D}_{\mathrm{v} 0.5}$ (VMD) is the droplet diameter where $50 \%$ of the spray volume is contained in droplets smaller than this value. Similarly, the $\mathrm{D}_{\mathrm{v} 0.1}$ and $\mathrm{D}_{\mathrm{v} 0.9}$ values are the diameters at which 10 and $90 \%$, respectively, of the spray volume, is contained in droplets of this size or less. Similar to previous studies
(Hoffmann et al. 2007a, 2007b, 2008, 2009), the objective of this work was to evaluate the operational performance of the individual nozzles. For this reason, the results are presented for each nozzle with no comparison or rating between nozzles. Each set of nozzle data is further separated by the measurement system with no comparison between systems. As a means of discussing the data, the labeled droplet size recommendations presented earlier for Fyfanon ${ }^{\circledR}$ and Anvil ${ }^{\circledR}$ are discussed. Ultimately, us- 
ers can review the droplet size data presented in tables 1-4 to determine if the droplet size requirements for the product they are spraying are met by the different atomizers tested.

\section{RESULTS}

The measured droplet sizes for the three nozzles operating under the specified conditions are shown in tables $1-4$.

\section{Micronair AU5000 Rotary Atomizer}

Generally, spray pressure increase corresponded to an increase in flow rate. These increases mean that droplet size also increased (Table 1). This increase is droplet size with pressure is consistent with the published literature (Hooper and Spurgin 1995; Teske et al. 2005). Looking at the Fyfanon ${ }^{\circledR}$ label requirement for $\mathrm{D}_{\mathrm{v} 0.5}<60 \mu \mathrm{m}$ and $\mathrm{D}_{\mathrm{v} 0.9}<100 \mu \mathrm{m}$, measurements from both laser diffraction systems indicated that use of the Micronair AU5000 (at the operational settings tested) is not acceptable for aerial applications. However, the PDPA system returned measurements that are acceptable. One potential reason for this, is that while the laser diffraction systems measure a composite traverse across the spray plume, the PDPA only measures droplets passing through a small $\left(1 \mathrm{~mm}^{2}\right)$ area. For this study, the mechanized structure needed to traverse the PDPA through the entire spray plume was not available, so the measurements recorded are representative of a vertical traverse through the center of the spray plume. This means that any variation in the spray plume to either side of center, was not captured in the PDPA measurements that were captured by the laser diffraction systems. The Anvil ${ }^{\circledR}$ label requirements of $8<\mathrm{D}_{\mathrm{v} 0.5}<30 \mu \mathrm{m}$ and $\mathrm{D}_{\mathrm{v} 0.9}<50 \mu \mathrm{m}$ and nozzle setup as measured by any of the three systems were not met.

\section{BETE PJ High Pressure Fog (Misting) Nozzles}

For both the 54 and $63 \mathrm{~m} / \mathrm{s}$ airstreams, droplet size increased as the orifice size increased and decreased as the spray pressure increased (Tables 2, 3). The Fyfanon ${ }^{\circledR}$ label requirements were met for all the operational setups and measurements systems in the $54 \mathrm{~m} / \mathrm{s}$ airstream, except for the $\mathrm{D}_{\mathrm{v} 0.9}$ requirement for the larger orifice setups as measured by the PDPA systems. Similarly, the Anvil ${ }^{\circledR}$ requirements were met for all the operational setups and measurement systems except for the larger orifice setups with all measurement systems. These trends hold for the same operational setups measured in the $63 \mathrm{~m} / \mathrm{s}$ airstream.

\section{TeeJet $^{\circledR}$ 8001E Even Flat Fan Nozzle}

The two spray pressures used, had little consistent effect on the measured droplet size. However, as expected, an increase in airspeed decreased the droplet size (Table 4$)$. While a few of the measured $\mathrm{D}_{\mathrm{v} 0.5}(\mathrm{VMD})$ values resulting from the operational setups met the Fyfanon ${ }^{\circledR}$ label requirements, none of the operational setups for any of the measurement systems met the $\mathrm{D}_{\mathrm{v} 0.9}$ requirement. Likewise, none of the operational setups evaluated by the three measurement systems met the Anvil ${ }^{\circledR}$ label requirements.

Table 1. Droplet sizes for the Micronair AU5000 rotary atomizer measured in a $63 \mathrm{~m} / \mathrm{s}$ (140 mph) airstream with BVA 13 ULV Oil

\begin{tabular}{|c|c|c|c|c|}
\hline \multicolumn{5}{|c|}{ Sympatec $^{a}$} \\
\hline Restrictor position & $\begin{array}{l}\text { liquid pressure } \\
(\mathrm{kPa}(\mathrm{psi})]\end{array}$ & $\begin{array}{c}\mathrm{D}_{\mathrm{v} 0.1} \mathrm{~b} \pm \mathrm{SD} \\
{[\mu \mathrm{m}]}\end{array}$ & $\begin{array}{c}\mathrm{D}_{\mathrm{v0.5}} \mathrm{b}_{ \pm} \mathrm{SD} \\
{[\mu \mathrm{m}]}\end{array}$ & $\begin{array}{c}\mathrm{D}_{\mathrm{v} 0.9} \mathrm{~b}^{\mathrm{b}} \pm \mathrm{SD} \\
{[\mu \mathrm{m}]}\end{array}$ \\
\hline \multirow{3}{*}{2} & $138(20)$ & $24.9 \pm 0.6$ & $60.8 \pm 0.4$ & $106.1 \pm 2.9$ \\
\hline & $276(40)$ & $24.6 \pm 4.2$ & $66.8 \pm 4.3$ & $118.4 \pm 2.9$ \\
\hline & $410(60)$ & $23.5 \pm 0.2$ & $67.9 \pm 0.4$ & $122.6 \pm 1.1$ \\
\hline \multirow{3}{*}{4} & $138(20)$ & $23.5 \pm 1.2$ & $68.1 \pm 2.0$ & $108.8 \pm 3.9$ \\
\hline & $276(40)$ & $26.1 \pm 0.2$ & $74.3 \pm 0.7$ & $121.1 \pm 1.5$ \\
\hline & $410(60)$ & $22.9 \pm 0.3$ & $61.3 \pm 0.8$ & $131.3 \pm 1.9$ \\
\hline & & Malvern & & \\
\hline Restrictor position & $\begin{array}{l}\text { liquid pressure } \\
{[\mathrm{kPa}(\mathrm{psi})]}\end{array}$ & $\begin{array}{c}\mathrm{D}_{\mathrm{v} 0.1} \pm \mathrm{SD} \\
{[\mu \mathrm{m}]}\end{array}$ & $\begin{array}{c}\mathrm{D}_{\mathrm{v} 0.5 .5 \mathrm{SD}} \\
{[\mu \mathrm{m}]}\end{array}$ & $\begin{array}{c}\mathrm{D}_{\mathrm{v} 0.9} \pm \mathrm{SD} \\
{[\mu \mathrm{m}]}\end{array}$ \\
\hline \multirow{3}{*}{2} & $138(20)$ & $16.7 \pm 0.1$ & $57.9 \pm 0.5$ & $160.0 \pm 18.8$ \\
\hline & $276(40)$ & $20.7 \pm 1.0$ & $69.4 \pm 2.4$ & $213.7 \pm 60.5$ \\
\hline & $410(60)$ & $21.9 \pm 0.2$ & $70.0 \pm 0.2$ & $145.5 \pm 2.5$ \\
\hline \multirow{3}{*}{4} & $138(20)$ & $22.5 \pm 0.7$ & $69.4 \pm 1.0$ & $128.4 \pm 5.0$ \\
\hline & $276(40)$ & $24.2 \pm 0.1$ & $72.9 \pm 0.6$ & $144.9 \pm 5.2$ \\
\hline & $410(60)$ & $17.3 \pm 0.2$ & $59.5 \pm 0.2$ & $151.5 \pm 1.7$ \\
\hline \multicolumn{5}{|c|}{ PDPA } \\
\hline Restrictor position & $\begin{array}{l}\text { liquid pressure } \\
{[\mathrm{kPa}(\mathrm{psi})]}\end{array}$ & $\begin{array}{c}\mathrm{D}_{\mathrm{v} 0.1} \pm \mathrm{SD} \\
{[\mu \mathrm{m}]}\end{array}$ & $\begin{array}{c}\mathrm{D}_{\mathrm{v} 0.5} \pm \mathrm{SD} \\
{[\mu \mathrm{m}]}\end{array}$ & $\begin{array}{c}\mathrm{D}_{\mathrm{v} 0.9} \pm \mathrm{SD} \\
{[\mu \mathrm{m}]}\end{array}$ \\
\hline \multirow{3}{*}{2} & $138(20)$ & $19.4 \pm 1.5$ & $47.0 \pm 3.0$ & $84.8 \pm 9.7$ \\
\hline & $276(40)$ & $23.0 \pm 0.4$ & $53.5 \pm 1.1$ & $91.3 \pm 2.5$ \\
\hline & $410(60)$ & $24.7 \pm 0.4$ & $54.6 \pm 0.4$ & $96.9 \pm 1.7$ \\
\hline
\end{tabular}

${ }^{a}$ means and standard are across the three replicated measurements taken at each operational setup point; ${ }^{b}$ the $\mathrm{D}_{\mathrm{v} 0.5}$ is the droplet diameter $(\mu \mathrm{m})$ where $50 \%$ of the spray volume is contained in droplets smaller than this value. $D_{v 0.1}$ and $D_{v 0.9}$ values are the diameters at which 10 and $90 \%$, respectively, of the spray volume is contained in droplets of this size or less; SD - standard deviation 
Table 2. Droplet sizes for the BETE PJ high pressure fog nozzles measured in a $54 \mathrm{~m} / \mathrm{s}$ (120 mph) airstream with BVA 13 ULV Oil

\begin{tabular}{|c|c|c|c|c|}
\hline \multicolumn{5}{|c|}{ Sympatec $^{\mathrm{a}}$} \\
\hline Nozzle type & $\begin{array}{l}\text { liquid pressure } \\
{[\mathrm{kPa}(\mathrm{psi})]}\end{array}$ & $\begin{array}{c}\mathrm{D}_{\mathrm{v} 0.1} \mathrm{~b}_{ \pm} \mathrm{SD} \\
{[\mu \mathrm{m}]}\end{array}$ & $\begin{array}{c}\mathrm{D}_{\mathrm{v} 0.5}^{\mathrm{b}} \pm \mathrm{SD} \\
{[\mu \mathrm{m}]}\end{array}$ & $\begin{array}{c}\mathrm{D}_{\mathrm{v} 0.9}{ }^{\mathrm{b}} \pm \mathrm{SD} \\
{[\mu \mathrm{m}]}\end{array}$ \\
\hline \multirow{2}{*}{ PJ15 } & $6,900(1000)$ & $6.2 \pm 0.1$ & $23.2 \pm 0.3$ & $42.2 \pm 0.6$ \\
\hline & $10,300(1500)$ & $3.6 \pm 0.1$ & $20.4 \pm 0.1$ & $36.2 \pm 0.1$ \\
\hline \multirow{2}{*}{ PJ20 } & $6,900(1000)$ & $7.7 \pm 0.6$ & $28.5 \pm 0.3$ & $51.2 \pm 2.0$ \\
\hline & $10,300(1500)$ & $3.1 \pm 0.0$ & $23.6 \pm 0.3$ & $40.6 \pm 0.4$ \\
\hline \multirow{2}{*}{ PJ24 } & $6,900(1000)$ & $7.8 \pm 0.1$ & $27.1 \pm 0.1$ & $49.4 \pm 0.3$ \\
\hline & $10,300(1500)$ & $3.2 \pm 0.1$ & $22.3 \pm 0.3$ & $40.0 \pm 1.0$ \\
\hline \multirow{2}{*}{ PJ32 } & $6,900(1000)$ & $13.7 \pm 0.8$ & $41.3 \pm 0.8$ & $66.2 \pm 1.2$ \\
\hline & $10,300(1500)$ & $8.8 \pm 1.9$ & $33.2 \pm 1.1$ & $52.0 \pm 1.0$ \\
\hline \multicolumn{5}{|c|}{ Malvern } \\
\hline Nozzle type & $\begin{array}{l}\text { liquid pressure } \\
{[\mathrm{kPa}(\mathrm{psi})]}\end{array}$ & $\begin{array}{c}\mathrm{D}_{\mathrm{v} 0.1} \pm \mathrm{SD} \\
{[\mu \mathrm{m}]}\end{array}$ & $\begin{array}{c}\mathrm{D}_{\mathrm{v} 0.5} \pm \mathrm{SD} \\
{[\mu \mathrm{m}]}\end{array}$ & $\begin{array}{c}\mathrm{D}_{\mathrm{v} 0.9} \pm \mathrm{SD} \\
{[\mu \mathrm{m}]}\end{array}$ \\
\hline \multirow{2}{*}{ PJ15 } & $6,9001000)$ & $5.8 \pm 0.2$ & $23.7 \pm 0.4$ & $46.9 \pm 0.4$ \\
\hline & $10,300(1500)$ & $4.3 \pm 0.1$ & $19.7 \pm 0.1$ & $38.5 \pm 0.2$ \\
\hline \multirow{2}{*}{ PJ20 } & $6,900(1000)$ & $7.2 \pm 0.1$ & $27.9 \pm 2.1$ & $53.3 \pm 0.2$ \\
\hline & $10,300(1500)$ & $4.8 \pm 0.0$ & $22.2 \pm 0.5$ & $44.4 \pm 1.1$ \\
\hline \multirow{2}{*}{ PJ24 } & $6,900(1000)$ & $9.6 \pm 0.3$ & $29.7 \pm 0.3$ & $57.5 \pm 0.5$ \\
\hline & $10,300(1500)$ & $5.3 \pm 0.1$ & $23.9 \pm 0.1$ & $46.3 \pm 0.4$ \\
\hline \multirow{2}{*}{ PJ32 } & $6,900(1000)$ & $17.7 \pm 1.0$ & $43.3 \pm 1.2$ & $77.7 \pm 0.7$ \\
\hline & $10,300(1500)$ & $8.6 \pm 0.2$ & $31.6 \pm 0.3$ & $56.2 \pm 1.0$ \\
\hline \multicolumn{5}{|c|}{ PDPA } \\
\hline Nozzle type & $\begin{array}{l}\text { liquid pressure } \\
{[\mathrm{kPa}(\mathrm{psi})]}\end{array}$ & $\begin{array}{c}\mathrm{D}_{\mathrm{v} 0.1} \pm \mathrm{SD} \\
{[\mu \mathrm{m}]}\end{array}$ & $\begin{array}{c}\mathrm{D}_{\mathrm{v} 0.5} \pm \mathrm{SD} \\
{[\mu \mathrm{m}]}\end{array}$ & $\begin{array}{c}\mathrm{D}_{\mathrm{v} 0.9} \pm \mathrm{SD} \\
{[\mu \mathrm{m}]}\end{array}$ \\
\hline \multirow{2}{*}{ PJ15 } & $6,900(1000)$ & $13.2 \pm 0.1$ & $22.1 \pm 0.3$ & $35.0 \pm 1.7$ \\
\hline & $10,300(1500)$ & $13.6 \pm 0.1$ & $21.5 \pm 0.3$ & $32.0 \pm 0.7$ \\
\hline \multirow{2}{*}{ PJ24 } & $6,900(1000)$ & $16.1 \pm 0.5$ & $29.7 \pm 1.6$ & $118.3 \pm 8.3$ \\
\hline & $10,300(1500)$ & $16.6 \pm 0.4$ & $29.5 \pm 1.2$ & $98.8 \pm 7.2$ \\
\hline \multirow{2}{*}{ PJ32 } & $6,900(1000)$ & $15.2 \pm 1.3$ & $22.8 \pm 1.5$ & $114.2 \pm 20.3$ \\
\hline & $10,300(1500)$ & $15.8 \pm 1.1$ & $24.0 \pm 1.6$ & $81.7 \pm 6.8$ \\
\hline
\end{tabular}

${ }^{a}$ means and standard are across the three replicated measurements taken at each operational setup point; ${ }^{\text {bthe }} \mathrm{D}_{\mathrm{v} 0.5}$ is the droplet diameter $(\mu \mathrm{m})$ where $50 \%$ of the spray volume is contained in droplets smaller than this value. $D_{v 0.1}$ and $D_{v 0.9}$ values are the diameters at which 10 and $90 \%$, respectively, of the spray volume is contained in droplets of this size or less; SD - standard deviation

Table 3. Droplet sizes for the BETE PJ high pressure fog nozzles measured in a $63 \mathrm{~m} / \mathrm{s}$ (140 mph) airstream with BVA 13 ULV Oil

\begin{tabular}{|c|c|c|c|c|}
\hline \multicolumn{5}{|c|}{ Sympatec $^{\mathrm{a}}$} \\
\hline Nozzle type & $\begin{array}{c}\text { liquid pressure } \\
{[\mathrm{kPa}(\mathrm{psi})]}\end{array}$ & $\begin{array}{c}\mathrm{D}_{\mathrm{v} 0.1}^{\mathrm{b}_{ \pm}} \pm \mathrm{SD} \\
{[\mu \mathrm{m}]}\end{array}$ & $\begin{array}{c}\mathrm{D}_{\mathrm{v} 0.5}^{\mathrm{b}} \pm \mathrm{SD} \\
{[\mu \mathrm{m}]}\end{array}$ & $\begin{array}{c}\mathrm{D}_{\mathrm{v} 0.9^{\mathrm{b}} \pm \mathrm{SD}}[\mu \mathrm{m}] \\
{[\mu \mathrm{m}}\end{array}$ \\
\hline \multirow{2}{*}{ PJ15 } & $6,900(1000)$ & $6.2 \pm 0.2$ & $22.6 \pm 0.2$ & $41.9 \pm 0.3$ \\
\hline & $10,300(1500)$ & $3.9 \pm 0.1$ & $19.6 \pm 0.2$ & $35.4 \pm 0.2$ \\
\hline \multirow{2}{*}{ PJ20 } & $6,900(1000)$ & $5.6 \pm 0.2$ & $24.7 \pm 0.2$ & $44.6 \pm 0.1$ \\
\hline & $10,300(1500)$ & $3.5 \pm 0.1$ & $20.6 \pm 0.2$ & $36.9 \pm 0.1$ \\
\hline \multirow{2}{*}{ PJ24 } & $6,900(1000)$ & $7.4 \pm 0.3$ & $28.2 \pm 0.4$ & $51.2 \pm 0.4$ \\
\hline & $10,300(1500)$ & $3.8 \pm 0.4$ & $23.6 \pm 0.7$ & $41.7 \pm 1.4$ \\
\hline \multirow{2}{*}{ PJ32 } & $6,900(1000)$ & $12.7 \pm 0.4$ & $40.0 \pm 0.7$ & $65.1 \pm 1.3$ \\
\hline & $10,300(1500)$ & $6.3 \pm 1.9$ & $30.9 \pm 1.2$ & $50.2 \pm 1.3$ \\
\hline \multicolumn{5}{|c|}{ Malvern } \\
\hline Nozzle type & $\begin{array}{l}\text { liquid pressure } \\
{[\mathrm{kPa}(\mathrm{psi})]}\end{array}$ & $\begin{array}{c}\mathrm{D}_{\mathrm{v} 0.1} \pm \mathrm{SD} \\
{[\mu \mathrm{m}]}\end{array}$ & $\begin{array}{c}\mathrm{D}_{\mathrm{v} 0.5} \pm \mathrm{SD} \\
{[\mu \mathrm{m}]}\end{array}$ & $\begin{array}{c}\mathrm{D}_{\mathrm{v} 0.9} \pm \mathrm{SD} \\
{[\mu \mathrm{m}]}\end{array}$ \\
\hline \multirow{2}{*}{ PJ15 } & $6,900(1000)$ & $5.6 \pm 0.1$ & $23.0 \pm 0.3$ & $47.6 \pm 0.3$ \\
\hline & $10,300(1500)$ & $4.9 \pm 0.1$ & $19.4 \pm 0.1$ & $39.0 \pm 0.2$ \\
\hline \multirow{2}{*}{ PJ20 } & $6,900(1000)$ & $6.2 \pm 0.1$ & $25.1 \pm 0.0$ & $49.1 \pm 0.9$ \\
\hline & $10,300(1500)$ & $4.5 \pm 0.1$ & $20.1 \pm 0.6$ & $41.2 \pm 0.9$ \\
\hline \multirow{2}{*}{ PJ24 } & $6,900(1000)$ & $9.2 \pm 0.4$ & $29.3 \pm 0.3$ & $56.9 \pm 0.4$ \\
\hline & $10,300(1500)$ & $5.5 \pm 0.3$ & $23.6 \pm 0.7$ & $52.2 \pm 12.5$ \\
\hline \multirow{2}{*}{ PJ32 } & $6,900(1000)$ & $17.5 \pm 0.3$ & $42.3 \pm 0.3$ & $75.5 \pm 1.0$ \\
\hline & $10,300(1500)$ & $8.1 \pm 0.8$ & $30.3 \pm 1.3$ & $56.4 \pm 3.1$ \\
\hline
\end{tabular}




\begin{tabular}{ccccc}
\hline & \multicolumn{5}{c}{ PDPA } & \\
\hline \multirow{2}{*}{ Nozzle type } & $\begin{array}{c}\text { liquid pressure } \\
{[\mathrm{kPa}(\mathrm{psi})]}\end{array}$ & $\begin{array}{c}\mathrm{D}_{\mathrm{v} 0.1 .1 \mathrm{SD}} \\
{[\mu \mathrm{m}]}\end{array}$ & $\begin{array}{c}\mathrm{D}_{\mathrm{v} 0.5} \pm \mathrm{SD} \\
{[\mu \mathrm{m}]}\end{array}$ & $\begin{array}{c}\mathrm{D}_{\mathrm{v} 0.9} \pm \mathrm{SD} \\
{[\mu \mathrm{m}]}\end{array}$ \\
\hline \multirow{2}{*}{ PJ15 } & $6,900(1000)$ & $13.5 \pm 0.2$ & $22.5 \pm 0.2$ & $36.2 \pm 1.1$ \\
& $10,300(1500)$ & $13.3 \pm 0.4$ & $21.5 \pm 0.3$ & $32.6 \pm 0.4$ \\
\hline \multirow{2}{*}{ PJ24 } & $6,900(1000)$ & $16.0 \pm 0.2$ & $28.3 \pm 0.8$ & $97.9 \pm 2.3$ \\
& $10,300(1500)$ & $16.9 \pm 0.4$ & $29.2 \pm 0.9$ & $87.3 \pm 4.3$ \\
\hline \multirow{2}{*}{ PJ32 } & $6,900(1000)$ & $14.0 \pm 0.2$ & $21.3 \pm 0.2$ & $76.4 \pm 9.2$ \\
& $10,300(1500)$ & $14.4 \pm 0.3$ & $21.9 \pm 0.3$ & $74.0 \pm 4.7$ \\
\hline
\end{tabular}

${ }^{a}$ means and standard are across the three replicated measurements taken at each operational setup point; ${ }^{b}$ the $D_{v 0.5}$ is the droplet diameter $(\mu \mathrm{m})$ where $50 \%$ of the spray volume is contained in droplets smaller than this value. $D_{v 0.1}$ and $D_{v 0.9}$ values are the diameters at which 10 and 90\%, respectively, of the spray volume is contained in droplets of this size or less; SD - standard deviation

Table 4. Droplet sizes for the TeeJet ${ }^{\circledR}$ 8001E even flat fan nozzle measured at a $135^{\circ}$ orientation to the airstream with BVA 13 ULV Oil

\begin{tabular}{|c|c|c|c|c|}
\hline \multicolumn{5}{|c|}{ Sympatec $^{\mathrm{a}}$} \\
\hline $\begin{array}{l}\text { air speed } \\
\mathrm{m} / \mathrm{s}[\mathrm{mph}]\end{array}$ & $\begin{array}{c}\text { liquid pressure } \\
{[\mathrm{kPa}(\mathrm{psi})]}\end{array}$ & $\begin{array}{c}\mathrm{D}_{\mathrm{v} 0.1}{ }^{\mathrm{b}} \pm \mathrm{SD} \\
{[\mu \mathrm{m}]}\end{array}$ & $\begin{array}{c}\mathrm{D}_{\mathrm{v} 0.5}{ }^{\mathrm{b}} \pm \mathrm{SD} \\
{[\mu \mathrm{m}]}\end{array}$ & $\begin{array}{c}\mathrm{D}_{\mathrm{v} 0.9}^{\mathrm{b}_{ \pm}} \pm \mathrm{SD} \\
{[\mu \mathrm{m}]}\end{array}$ \\
\hline \multirow{2}{*}{$54(120)$} & $276(40)$ & $18.7 \pm 0.2$ & $56.7 \pm 0.3$ & $127.3 \pm 2.4$ \\
\hline & $410(60)$ & $20.1 \pm 0.4$ & $71.0 \pm 6.0$ & $146.4 \pm 3.2$ \\
\hline \multirow{2}{*}{$63(140)$} & $276(40)$ & $15.8 \pm 0.8$ & $56.8 \pm 2.6$ & $113.0 \pm 6.3$ \\
\hline & $410(60)$ & $14.7 \pm 0.3$ & $52.4 \pm 0.8$ & $104.4 \pm 0.3$ \\
\hline \multicolumn{5}{|c|}{ Malvern } \\
\hline $\begin{array}{l}\text { air speed } \\
\mathrm{m} / \mathrm{s}[\mathrm{mph}]\end{array}$ & $\begin{array}{c}\text { liquid pressure } \\
{[\mathrm{kPa}(\mathrm{psi})]}\end{array}$ & $\begin{array}{c}\mathrm{D}_{\mathrm{v} 0.1}{ }^{\mathrm{b}} \pm \mathrm{SD} \\
{[\mu \mathrm{m}]}\end{array}$ & $\begin{array}{c}\mathrm{D}_{\mathrm{v} 0.5}{ }^{\mathrm{b}} \pm \mathrm{SD} \\
{[\mu \mathrm{m}]}\end{array}$ & $\begin{array}{c}\mathrm{D}_{\mathrm{v} 0.9^{\mathrm{b}} \pm \mathrm{SD}}[\mu \mathrm{m}] \\
\end{array}$ \\
\hline \multirow{2}{*}{$54(120)$} & $276(40)$ & $32.4 \pm 4.0$ & $74.4 \pm 7.0$ & $178.5 \pm 13.3$ \\
\hline & $410(60)$ & $30.1 \pm 0.9$ & $68.3 \pm 1.1$ & $157.3 \pm 3.6$ \\
\hline \multirow{2}{*}{$63(140)$} & $276(40)$ & $22.2 \pm 11.5$ & $62.8 \pm 7.9$ & $204.7 \pm 82.3$ \\
\hline & $410(60)$ & $24.7 \pm 0.6$ & $64.4 \pm 2.0$ & $308.6 \pm 112.1$ \\
\hline \multicolumn{5}{|c|}{ PDPA } \\
\hline $\begin{array}{l}\text { air speed } \\
\mathrm{m} / \mathrm{s}[\mathrm{mph}]\end{array}$ & $\begin{array}{l}\text { liquid pressure } \\
{[\mathrm{kPa}(\mathrm{psi})]}\end{array}$ & $\begin{array}{c}\mathrm{D}_{\mathrm{v} 0.1}{ }^{\mathrm{b}} \pm \mathrm{SD} \\
{[\mu \mathrm{m}]}\end{array}$ & $\begin{array}{c}\mathrm{D}_{\mathrm{v} 0.5}{ }^{\mathrm{b}} \pm \mathrm{SD} \\
{[\mu \mathrm{m}]}\end{array}$ & $\begin{array}{c}\mathrm{D}_{\mathrm{v} 0.9}{ }^{\mathrm{b}} \pm \mathrm{SD} \\
{[\mu \mathrm{m}]}\end{array}$ \\
\hline \multirow{2}{*}{$63(140)$} & $276(40)$ & $37.6 \pm 2.2$ & $71.1 \pm 4.7$ & $128.9 \pm 2.8$ \\
\hline & $410(60)$ & $32.7 \pm 1.2$ & $57.7 \pm 2.4$ & $106.5 \pm 9.9$ \\
\hline
\end{tabular}

${ }^{a}$ means and standard are across the three replicated measurements taken at each operational setup point; ${ }^{b}$ the $\mathrm{D}_{\mathrm{v} 0.5}$ is the droplet diameter $(\mu \mathrm{m})$ where $50 \%$ of the spray volume is contained in droplets smaller than this value. $D_{v 0.1}$ and $D_{v 0.9}$ values are the diameters at which 10 and $90 \%$, respectively, of the spray volume is contained in droplets of this size or less; SD - standard deviation

\section{DISCUSSION}

The state of FL has 52 mosquito control programs, with an annual budget in 2006-2007 of approximately \$150 million dollars (Latham 2008). In many of these programs, the aerial application of adulticides from helicopters and fixed-wing aircraft, make up the greatest percentage of acreage sprayed for mosquito control. The presented data will help applicators select spray equipment and operational parameters that support a particular spray mission. Latham and Barber (2007) concluded that based on operational evaluations in a number of mosquito control districts, sprays that created a $D_{v 0.5}$ (VMD) in the 25-35 $\mu \mathrm{m}$ range, provided the best control of adult mosquitoes.

Spray droplet size is a critical factor that impacts the efficacy of products applied to control mosquitoes and other disease carrying arthropods. Accordingly, evaluating the spray droplet size resulting from select application technologies used, is needed prior to field scale treatment. The objective of this work was to evaluate a number of typical aerial application nozzles and operational setups used for vector control operations, so the suitability of the nozzles and operational setups for applying selected adulticides could be determined.
Based on the results of this work, only the BETE PJ high pressure nozzles met the label requirements for both Fyfanon $^{\circledR}$ and Anvil ${ }^{\circledR}$. While the other nozzle might meet the $D_{v 0.5}(V M D)$ requirement for Fyfanon ${ }^{\circledR}$, the resulting $\mathrm{D}_{\mathrm{v} 0.9}$ values exceeded the labeled size restrictions. When applying Anvil ${ }^{\circledR}$ with the BETE PJ high pressure nozzles, it is important to use the smaller two orifice sizes (PJ15 and PJ20). The larger orifice sizes (PJ24 and PJ32) tend to result in $\mathrm{D}_{\mathrm{v} 0.9}$ values that exceed label recommendations. These conclusions support studies conducted by Dukes et al. (2004a, 2004b), who reported higher mortality and lower ground depositions for high pressure nozzles as compared to flat fan nozzles.

\section{ACKNOWLEDGMENTS}

This study was supported in part by a grant from the Deployed War-Fighter Protection (DWFP) Research Program, funded by the U.S. Department of Defence through the Armed Forces Pest Management Board (AFPMB). The authors would also like to thank Charlie Harris and Lee Denham for their assistance during the testing. 


\section{REFERENCES}

ASTM International 2004. American Society for Testing Materials Standard E1620: Terminology Relating to Liquid Particles and Atomization. Annual Book of ASTM Standards, ASTM International, West Conshohocken, PA, 7 pp.

Clayton J.S., Sander T.P.Y. 2002. Aerial application for control of public health pests. Aspects Appl. Biol. 66: 371-378.

Dukes J.C., Zhong H., Greer M., Hester P., Hogan D., Barber J.A.S. 2004a. A comparison of two spray nozzle systems used to aerially apply the ultra-low-volume adulticide Fenthion. J. Am. Mosq. Control Assoc. 20 (1): 27-35.

Dukes J.C., Zhong H.E., Greer M., Hester P.G., Hogan D., Barber J.A.S. 2004b. A comparison of two ultra-low volume spray nozzle systems by using a multiple swath scenario for the aerial application of fenthion against caged mosquitoes. J. Am. Mosq. Control Assoc. 20 (1): 36-44.

Haile D.G., Mount G.A., Pierce N.W. 1982. Effect of droplet size of malathion aerosols on kill of caged adult mosquitoes. Mosq. News 42 (4): 576-583.

Hoffmann W.C., Walker T.W., Martin D.E., Barber J.A.S., Gwinn T.L., Smith V., Szumlas D., Lan Y., Fritz B.K. 2007a. Characterization of truck-mounted atomization equipment used in vector control. J. Am. Mosq. Control Assoc. 23 (3): 315-320.

Hoffmann W.C., Walker T.W., Smith V.L., Martin D.E., Fritz B.K. 2007b. Droplet-size characterization of handheld atomization equipment typically used in vector control. J. Am. Mosq. Control Assoc. 23 (3): 312-314.

Hoffmann W.C., Walker T.W., Fritz B.K., Gwinn T., Smith V.L., Szumlas D., Quinn B., Lan Y., Huang Y., Sykes D. 2008. Spray characterization of thermal fogging equipment typically used in vector control. J. Am. Mosq. Control Assoc. 24 (4): 550-559.

Hoffmann W.C., Walker T.W., Gwinn T., Smith V.L., Szumlas D., Lan Y., Fritz B.K. 2009. Spray chararacterization of ultra-low volume sprayers typically used in vector control. J. Am. Mosq. Control Assoc. 25 (3): 332-337.

Hooper G.H.S., Spurgin P.A. 1995. Droplet size spectra produced by the atomization of a ULV formulation of fenitrothion with a Micronair AU5000 rotary atomizer. Crop Prot. 14 (1): 27-30.

Kirk I.W. 2007. Measurement and prediction of atomization parameters from fixed-wing aircraft spray nozzles. Trans. Am. Soc. Agric. Biol. Eng. ASABE 50 (3): 693-703.

Latham M.D. 2008. Aerial adulticiding to control adult mosquitosin Florida: 10 years of improvements in understanding and technology. Aspects Appl. Biol. 84: 281-288.

Latham M., Barber J. 2007. Mosquito control in Florida with a focus on aerial adulticiding. Outlooks Pest Manag. 18 (4): 178-183.

Ledson M., Matthews G.A. 1992. Droplet spectra with thermal foggers. Aspects Appl. Biol. 33: 125-130.

Lothrop H.D., Huang H.Z., Lothrop B.B., Gee S., Gomsi D.E., Reisen W.K. 2007. Deposition of pyrethrins and piperonyl butoxide following aerial ultra-low-volume application in the Coachella Valley, California. J. Am. Mosq. Control Assoc. 23 (2): 213-219.

Mabbett T. 2002. Insect vector-borne diseases and their control by aerial application. Int. Pest Control. 44: 307-309.

Mount G.A. 1985. Ultra-Low-Volume Application of Insecticides for Vector Control. Geneva, World Health Organization, unpublished document WHO/VBC/85.919; available on request from Division of Control of Tropical Diseases, WHO, 1211 Geneva 27, Switzerland, 31 pp.

Teske M.E., Thistle H.W., Hewitt A.J., Kirk I.W., Dexter R.K., Ghent J.H. 2005. Rotary atomizer drop size distribution database. Trans. ASAE 48: 917-921.

WHO. 2006a. Equipment for Vector Control: Specification Guidelines. Geneva, World Health Organization, 58 pp.

WHO. 2006b. Pesticides and their Application. 6th ed. Geneva, World Health Organization, 113 pp. 